\title{
Recent blue oak mortality on Sierra Nevada foothill rangelands may be linked to drought, climate change
}

\begin{abstract}
UC Cooperative Extension and landowners join forces to probe possible causes of mysterious blue oak mortality in the Sierra foothills.
\end{abstract}

by Dan Macon, Tracy Schohr, Doug Schmidt and Matteo Garbelotto

Online: https://doi.org/10.3733/ca.2020a0016

A dying blue oak (foreground) in Butte County with healthy blue oaks in the background. $\mathrm{n}$ the course of their everyday activities, like fencing, checking livestock health and assessing forage growth, ranchers are often among the first to observe changes in the landscape.

This research brief describes how rancher observations of blue oak tree mortality in the Sierra Nevada foothills prompted an investigation by UC Cooperative Extension scientists and the rapid identification of likely causes for the tree loss.

During the first week of June 2019, two foothill cattle producers contacted author Macon about an unusual number of dead and dying blue oaks on their annual rangelands in Placer and Nevada counties. Other reports of blue oak mortality emerged in the foothill region, including Butte County, where ranchers and landowners reached out to author Schohr. Reports indicated that diseased or dead oaks of different size classes were intermixed with what appeared to be healthy trees.

Macon conducted a field visit after the calls and observed the following conditions:

- Some trees that had been observed with normal leaf out in the spring appeared to be entirely dead and devoid of leaves by early summer.

- Several trees appeared to be dying from the top down or on individual branches. Many of the leaves on these trees also appeared to be scorched.

- These trees did not appear to have any lesions on their trunks - no wounds or noticeable fungal growth.

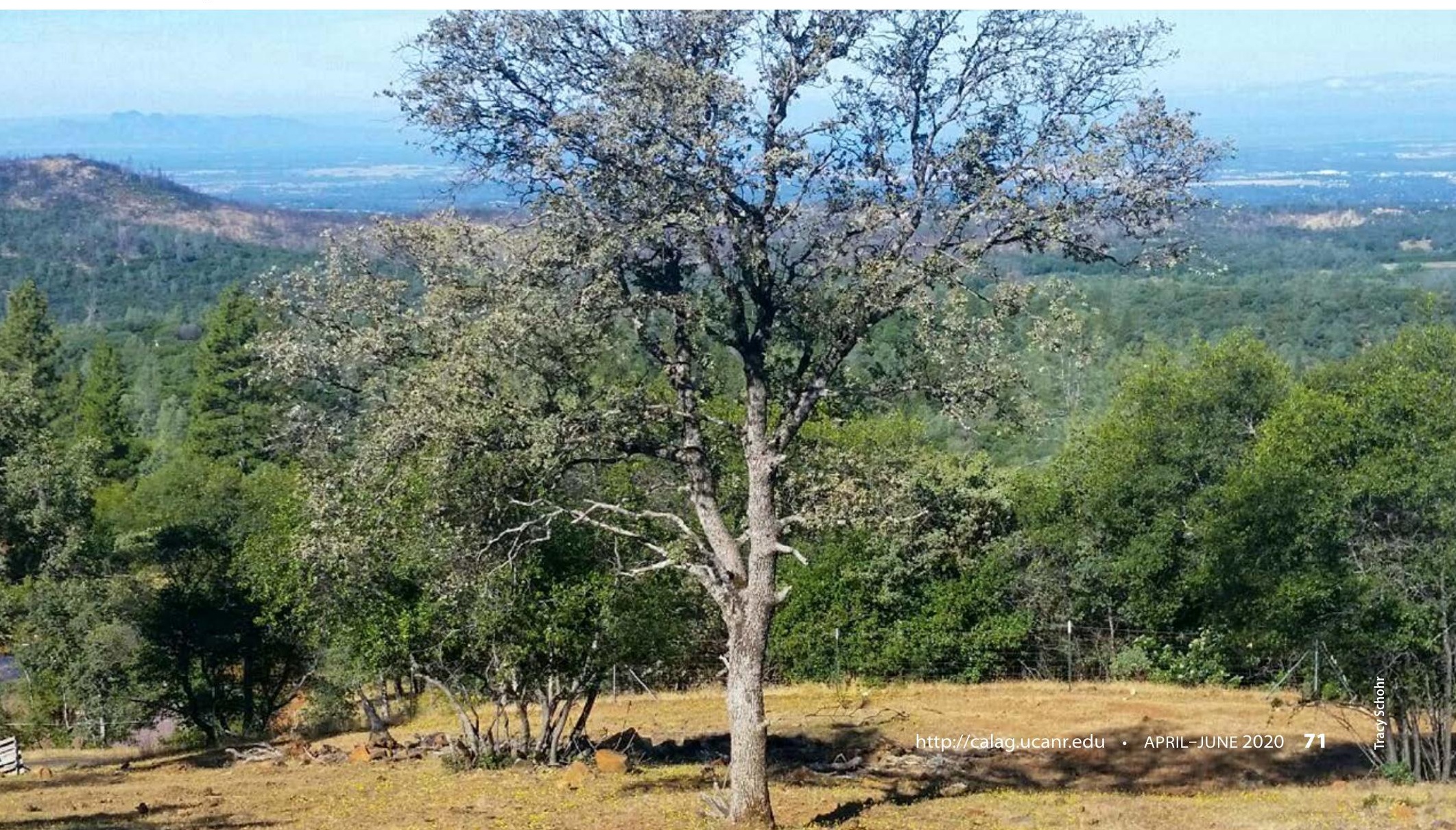


Macon contacted author Garbelotto, who has studied a variety of tree diseases. Garbelotto suggested collecting samples from foothill oaks for analysis. In early August, author Schmidt, who works with Garbelotto in the UC Berkeley Forest Pathology and Mycology Lab (www.matteolab.org), joined Macon to collect samples. Samples collected included leaves with evidence

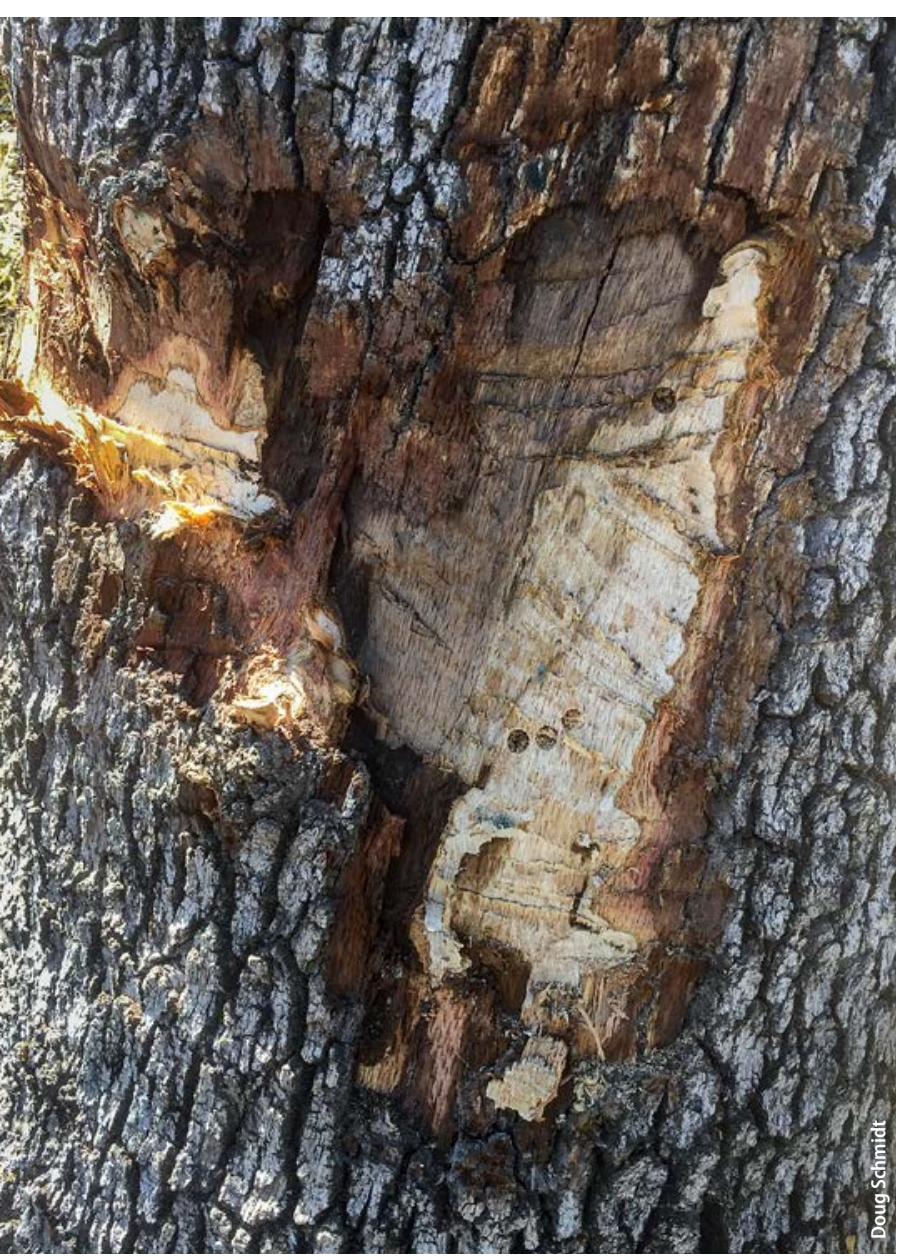

Wood tissue from a blue oak in Placer County with staining associated with developing Botryosphaeria canker. of scorching, soil samples from the base of symptomatic trees and wood samples from the trunks at eight sites in Placer and Yuba counties. Wood was collected at breast height, at the root collar and/or where obvious symptoms such as discoloration and decay were present. No obvious insect activity was detected at any of the sites.

Samples underwent a series of laboratory tests, including:

- testing soil and fine roots for the presence of pathogens in the genus Phytophthora, the cause of sudden oak death;

- plating wood chips on a variety of culture media and on carrot disks to identify a broad range of pathogens, including Fusaria, Raffaelea and Ceratocystis spp., that are known to cause oak wilt diseases;

- performing DNA analysis (www.wooddecay.org) on wood samples designed to identify serious tree pathogens, including species of Armillaria, Ganoderma, Hericium, Heterobasidion, Inonotus/ Phellinus, Laetiporus, Perenniporia, Pleurotus, Schizophyllum, Stereum and Trametes, among others (Nicolotti 2009); and

- testing scorched leaves and associated twigs (tests were performed by Dr. Rodrigo Almeida, UC Berkeley) for the presence of the bacterium Xylella fastidiosa, known to cause disease in oaks and other tree species.
All tests were negative, except for direct culturing of wood chips at breast height resulting in the growth of Botryosphaeria (synonym Diplodia) spp., specifically Botryosphaeria corticola and B. dothidea. These two species are native to California, and have been known to cause a lethal canker disease in some California oak species. Susceptibility to Diplodia is known to be genetically regulated in oak species, meaning that some families are more susceptible than others. Susceptibility can be greatly enhanced by predisposing factors, such as drought and infection by other primary pathogens, often root infection by Phytophthora species.

Based on the testing results, the working hypotheses is that recent drought events and overall climate change is causing an increased and widespread susceptibility of blue oaks to Botryosphaeria oak canker caused by Diplodia corticola and other Diplodia spieces. An alternative hypothesis is that a yet unknown pathogen may be increasing the susceptibility of blue oak to Botryosphaeria oak canker disease.

Additionally, the interaction between genetic driven susceptibility and limiting ecological conditions may explain the rather haphazard distribution of diseased trees, which do not appear to be clustered next to each other or to be prevalent in specific and similar topographic conditions (e.g., more abundant in draws, riparian habitats, ridges, etc.).

Interestingly, blue oak is not yet an official host for these two pathogens in the U.S. Department of Agriculture fungus-host database (https://nt.ars-grin. gov/fungaldatabases/fungushost/FungusHost.cfm). Hence, the observed infections may be the result either of a recent host jump or of an emergence of diseases once rare in this host.

In both cases, one of the possible outcomes of the observed mortality is a decrease in size and genetic diversity of populations of blue oaks in the Sierra Nevada foothills, with cascading effects on biodiversity and on the quality of pastures in associated rangelands.

In the spring of 2020, the UC Berkeley Forest Pathology Laboratory will be working with local UC Cooperative Extension agents at the county level to officially confirm the status of blue oaks as hosts of $D$. corticola and $D$. dothidea through controlled inoculation experiments.

\footnotetext{
D. Macon is UC Cooperative Extension (UCCE) Livestock and Natural Resources Advisor in Placer, Nevada, Sutter and Yuba counties; T. Schohr is UCCE Livestock and Natural Resources Advisor in Butte, Plumas and Sierra counties; D. Schmidt is Research Associate and Lab Manager, and M. Garbelotto is UCCE Specialist and Adjunct Associate Professor in the UC Berkeley Forest Pathology Laboratory.
}

\section{Reference}

Nicolotti, G, Gonthier P, Guglielmo F, Garbelotto M. 2009. A biomolecular method for the detection of wood decay fungi: A focus on tree stability assessment. Arboric Urb Forest 35(1):14-9. 